Investigations

\title{
Estimate of Damage on Mesquite Pods and Seeds (Prosopis laevigata (Willd) M.C. Johnst) (Mimosoideae) Caused by Bruchids (COLEOPTERA) in the Municipality of Durango, Durango, Mexico
}

\author{
Karina Lisbet Reséndez-Velázquez and María Pioquinta González-Castillo \\ Interdisciplinary Research Centre for Integral Regional Development-Durango, \\ National Polytechnique Institute (CIIDIR-IPN-Dgo), Durango, Durango, Mexico
}

\author{
Article history \\ Received: 11-12-2015 \\ Revised: 01-04-2016 \\ Accepted: 14-04-2016 \\ Corresponding Author: \\ María Pioquinta González- \\ Castillo \\ Interdisciplinary Research \\ Centre for Integral Regional \\ Development-Durango, \\ National Polytechnique \\ Institute (CIIDIR-IPN-Dgo) \\ Durango, Durango. Mexico \\ Email: gcmary01@hotmail.com
}

\begin{abstract}
Damage caused by weevils or bruchids in mesquite plants (Prosopis laevigata), in the municipality of Durango was established by infestation index. Immature and mature pods were obtained from 22 bushes during the months of June to September 2013. The pods were placed in emergence chambers, maintained at a temperature of $35 \pm 2{ }^{\circ} \mathrm{C}$ and $70 \pm 10 \%$ $\mathrm{RH}$, until adults were obtained. In June, 1,761 immature pods were obtained of which $76 \%$ were damaged (perforations); in August 713 mature pods were obtained with $90 \%$ damage. Observed bruchids species feeding on the pods and seed of mesquite were Algarobius prosopis and Mimosestes amicus (Bruchinae) with relative abundance of 76 and 19\% respectively and an average infestation index of $83,2 \%$ on pods. Natural enemies that were present were the parasitoids Urosigalphus sp. (Braconidae) and Horismenus missouriensis (Chalcidoidea: Eulophidae) with $2 \%$ relative abundance. From the total 105 pods damaged by insects, 1,188 seeds had $69,2 \%$ bruchid damage. Bruchids control is necessary in order to be able to obtain benefits from the mesquite pods and this can be done mainly through parasitoids that are associated with them. This electronic document is a "live" template. The various components of your paper [title, text, tables, figures and references] are already defined on the style sheet, as illustrated by the portions given in this document.
\end{abstract}

Keywords: Infestation Index, Algarobius prosopis, Mimosestes amicus, Parasitoids

\section{Introduction}

The Prosopis genus has approximately 45 species distributed in the arid and semi-arid areas of America, Africa and West Asia (Burkart, 1976; Palacios et al., 2000); of these, 43 species are found in America in two large regions: Mexico-Texas and Argentina-ParaguayChile (Carrillo, 2006; Loeza, 2007). In Mexico, 15 species have been reported distributed in 26 States (Arellano, 1996; Carrillo, 2006; Palacios, 2006; Ruiz, 2011; Garcia-Andrade et al., 2013) and of these, two species are located in Durango: Prosopis glandulosa Torr and P. laevigata (Willd) M.C. Johnst). This last one is found in 15 States of the Mexican Republic. In this country, mesquite and carob species are known for their ecological distribution, evolution, economic, social and ethnobotanical importance, amongst others (Meza and Osuna, 2003; Díaz et al., 2004; Carrillo, 2006; Alvarez and Villagra, 2009; Ruiz, 2011). Nevertheless, there have been losses of this resource and economic yield reduction due to over-harvesting, human impingement on the habitat, fires, climatic change and lack of a management plan, which in turn causes weakening of the mesquite making it vulnerable to pests and diseases (Flores-Flores et al., 2006; Rodriguez et al., 2014).

Worldwide, there have been some studies on parasites of foliage, blossoms, sheaths, pods and seeds, of which we can mention the studies by (Moran et al., 1993; Zachariades et al., 2011), carried out in South Africa, where damage to mesquite can be up to $90 \%$. Yet, this is good for this country since the mesquite, for them, is an invasive plant and they free specimens 
of $A$. prosopis and $A$. bottimeri Kingsolver as biological controls. Diaz (1995) mentioned that the Peruvian boll weevil Anthonomus vestitus Bohm causes damage to blooms and shoots of the carob tree. Likewise, Amdor et al. (2006) found that Algarobius bottimeri Kingsolver and Minosestes amicus (Horn) bruchids on Prosopis glandulosa var. glandulosa Torr. with a density of 97 and 3\% respectively in Texas where both oviposit in mature and immature pods, yet $M$. amicus prefers green pods.

In Mexico, Salas-Araiza et al. (2001), found 44\% damage in seeds of $P$. leavigata caused by Algarobius johnsoni Kingsolver, in Guanajuato, in the area known as el Bajio. Flores-Flores et al. (2006) carried out a study in Coahuila, finding that the main pest of mesquite is the twig girdler Oncideres cingulata (Say) and the next pest in importance is Dinoderus sp. known as the borer of shoots and twigs.

There are relatively few studies carried out in the State of Durango, on this subject. We can mention the study by (Solorio et al., 2004), who assessed the damage produced by Algarobius prosopis LeConte, in two locations of Durango: Rancho Meraz, Tlahualilo and Ejido San Isidro, Mapimi, where damage was observed with an average of $41.2 \%$ in covered pods and $46.9 \%$ in naked pods. Meanwhile, in the Meraz ranch, the damage percentage was $36.5 \%$ in covered pods and $32.1 \%$ in the naked ones. Likewise, Ramirez (2011), in Bermejillo, Durango, observed Heterospilus sp. and Urosigalphus sp. as natural enemies of Algarobius sp. and Acanthoselides sp. found on mesquite. Reyes et al. (2012) reported the Megacyllene antennata (White) borer as a potential pest of recently cut round wood used as posts for fences, in the mesquite zones, of the State of Durango.

Of the insect species described for mesquite, the Bruchidae family is the one that is most harmful for the fruit. There are five genus that feed exclusively on the seeds of this shrub: Algarobius (from North America to Venezuela and Hawaii), Neltumius (Southwest of the United States and North of Mexico), Pectinibruchus (Argentina), Rhipibruchus (Argentina, Chile and Uruguay) and Scutobruchus (Argentina, Chile, Peru and Ecuador) (Johnson, 1983; Rodriguez et al., 2014).

In the State of Durango, there are 44,211 hectares of mesquite, distributed in 14 municipalities. In 1992, the municipality of Durango, had mesquite on 444 ha, which have gradually been reduced to 371 ha in 2002, mainly because it has been used as firewood to produce charcoal (Trucios-Caciano et al., 2012) and also due to changes in land use, agricultural activities, encroachment by human dwellings, induced grazing lands and portions without apparent vegetation (Vallejo et al., 2012). In this municipality, diverse types of damage have been observed affecting $P$. laevigata populations; stalks with black spots from which a reddish gum or resin drips and harm to the pods and seeds that show insect bites and malformations amongst others (Personal Observations). What insects are causing this damage to the pods and a seed is unknown and the objective of this study was to identify the bruchid species, as well as assess the damage done, by means of the Infestation Index of mesquite pods and seeds, in the Ejido Aquiles Serdan of the Durango Municipality.

\section{Materials and Methods}

Study area. The study was carried out in the Ejido Aquiles Serdan, of the Durango municipality, that is located at $23^{\circ} 55^{\prime} 32.54^{\prime \prime}$ latitude north and $104^{\circ} 34^{\prime} 10.55^{\prime \prime}$ longitude west, at elevation $1892 \mathrm{~m}$, with an average annual rainfall of $518.88 \mathrm{~mm}$. Temperatures, for the year 2013, were $9.5^{\circ} \mathrm{C}$ minimum and $25.6^{\circ} \mathrm{C}$ maximum with a mean annual temperature of $17.4^{\circ} \mathrm{C}$ (INIFAP, 2013). The sampling period occurred during the development of the immature pods, in the month of June and from the mature pods, in August of 2013.

A surface of $10 \mathrm{ha}^{-1}$ was stratified for sampling on surfaces where the shrubs in the mesquite population were approximately four meters high. The surface was divided into 220 quadrants (strata), of 30 by $30 \mathrm{~m}$. Ten percent of these were randomly selected as study sites. In each site, the number of shrubs was quantified and one was randomly selected reaching a total of 22 shrubs, which were marked and labeled in order to perform insect collection from pods of each one. Likewise, each site was georeferenced with GPS TeK (Global Positioning System) Garmin.

Pod collection. At the beginning of foliage development, two branches were chosen from each marked shrub, one for the collection of immature pods and another for the collection of mature ones and each were in turn marked and labeled. In June and August, the immature and mature pods were respectively cut and placed in glazed paper bags, then labelled with their respective field information. Samples were then taken to the laboratory for total quantification of pods, separating the ones harmed (with perforations by the emergence of adult bruchids) from the healthy ones.

Collection of bruchids from immature and mature pods. Mature and immature pods that showed harm were maintained, during approximately two months, in emergence chambers (plastic containers with lid and breathing hole) in order to allow the emergence of adults. Once or twice a week the adults were taken from the containers, in order to avoid oviposition by the females and overgrowth of the pest population. Afterwards, the taxonomic classification was performed and the amounts of individuals per species were counted. Coleoptera order was classified using the taxonomic keys described by (Moron and Terron, 1988; Johnson, 1983). Dr. J. Refugio Lomeli Flores identified the parasitoid Horismenus missouriensis and Dr. Gabriela 
Castaño Meneses classified the formicidae species. Insects were deposited in the Entomological Collection of the Interdisciplinary Research Center for Regional Integral Development, Durango Unit, of the National Polytechnic Institute (CIIDIR-IPN, Durango Unit).

Assessment of damage percentage by means of the Infestation Index (I.I) in mature and immature pods. This index is a percentage and is an indicator of harm, estimated through the formula proposed by (Aguado and Suarez, 2006):

$$
\mathrm{I} . \mathrm{I}=\left(\frac{\text { total harmed pods }}{\text { total pods }}\right) \times 100
$$

Assessment of harmed seed percentage. Five damaged pods (perforated) were obtained from each tree from locations randomly selected. Seeds were extracted, carefully, by means of electrician's pliers, trying not to harm them. The damaged seeds were separated from the healthy ones and counted, to establish the percentage of damaged seeds by the same formula proposed by Aguado and Suarez (2006), modified for seeds.

Statistical Analysis. Species absolute abundance (N) was detected for immature and mature pods, as well as relative abundance $(\%)$. Frequency of species occurrence, per type of pod, established the relative abundance.

\section{Results}

Total pods. In June, 1,761 immature pods were collected and in August, 713 mature pods (Fig. 1).

Bruchids from immature and mature pods. From the emergence chambers, two bruchids were obtained: Algarobius prosopis le Conte and Mimosestes amicus (Horn) (Bruchinae). Their natural enemies are the hymenopterans: Urosigalphus sp. (Braconidae) and Horismenus missouriensis Ashmead (Eulophidae). It must be mentioned that from the mature pods came also the Crematogaster depilis Wheeler and Forelius pruinosus (Roger) (Formicidae) ants and a Lepidoptera, of undetermined species, was obtained from both immature and mature pods. Table 1 shows the total amount of insects and the relative abundance of the species per collection period: June (immature pod) and August (mature pod) respectively, where the A. prosopis and M. amicus bruchids were the ones of greater relative abundance.

Infestation index of immature and mature pods. Table 2 , presents the Infestation Index (I.I) of the immature and mature pods, caused by $A$. prosopis and $M$. amicus bruchids, with an average of $83.2 \%$ infested pods, where the month of August was the period with a higher infestation index.

Percentage of damaged seeds. From 105 mature pods, 1,188 seeds were obtained, of which $69.2 \%$ were damaged and $30.8 \%$ were healthy seeds.

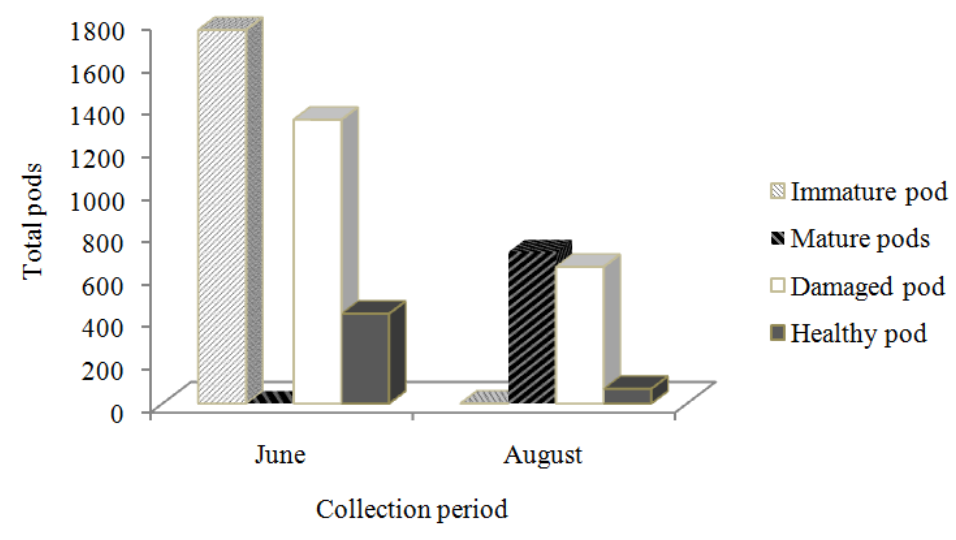

Fig. 1. Total in mature, mature, healthy and damaged pods found in the shrubs sampled during both recollection periods: June and August in the Ejido Aquiles Serdan, municipality of Durango

Table 1. Emergence $(\mathrm{N})$ and relative insect abundance in mature and mature mesquite pods in the Ejido Aquiles Serdan, municipality of Durango

\begin{tabular}{|c|c|c|c|c|c|c|}
\hline \multirow[b]{2}{*}{ Order } & \multirow[b]{2}{*}{ Family } & \multirow[b]{2}{*}{ Genus and/or species } & \multicolumn{2}{|c|}{ Immature pod } & \multicolumn{2}{|c|}{ Mature pod } \\
\hline & & & $\mathrm{N}$ & $\%$ & $\mathrm{~N}$ & $\%$ \\
\hline \multirow[t]{2}{*}{ Coleoptera } & Bruchidae & Algarobiusprosopisle Conte & 183 & 73.2 & 1,656 & 77.00 \\
\hline & & Mimosestes amicus (Horn) & 21 & 8.4 & 427 & 19.80 \\
\hline \multirow[t]{4}{*}{ Hymenoptera } & Braconidae & Urosigalphus sp. & 33 & 13.2 & 14 & 0.70 \\
\hline & Eulophidae & Horismenusmissouriensis Ashmead & 6 & 2.4 & 41 & 1.90 \\
\hline & Formicidae & Crematogasterdepilis Wheeler & 0 & 0.0 & 5 & 0.20 \\
\hline & & Foreliuspruinosus Roger & 0 & 0.0 & 1 & 0.05 \\
\hline Lepidoptera & Not specified & Not specified & 7 & 2.8 & 8 & 0.40 \\
\hline Total & & & 250 & 100.0 & 2,152 & 100.00 \\
\hline
\end{tabular}


Table 2. Infestation of mesquite pods P. laevigata, by A. prosopis and M. amicus bruchids in the Ejido Aquiles Serdan, Municipality of Durango, Durango

\begin{tabular}{lllll}
\hline Pod development & Pods $(\mathrm{N})$ & Healthy pods & Damaged pods & I. I.*(\%) \\
\hline Immature & 1,761 & 423 & 1,338 & 75.9 \\
Mature & 713 & 69 & 644 & 90.3 \\
Total & 2,472 & 492 & 1,982 & 83.2 \\
\hline
\end{tabular}

* I..I. = Infestation Index

\section{Discussion}

Total amount of pods. The total amount of pods $(2,472)$ was less than what was collected by Aguado and Suarez (2006). This difference exists because said authors collected in 14 sites and they collected pods from the trees and the ground. Likewise, Aubeterre et al. (2012) mentioned that they collected a total of 3,600 pods from nine places in the State of Lara-Venezuela and they quantified damages but they do not mention the total amount of these damages. They only indicated that damage by bruchids was detected. To know what pods come from the trees is indispensable in order to determine production by tree and hectare and thus be able to discard those that are damaged and use and store production better.

Bruchids from immature and mature pods. $A$. prosopis was the most abundant (Table 1) and perhaps that is due to the fact that the species limits it's feeding to Prosopis or as is mentioned by Kingsolver (2004), this species is the main bruchid that attacks mesquite pods. Likewise, it has been stated that the A. prosopis female deposits its eggs within clefts or openings of the pod and that the oviposition period begins in May, when the immature pods start to form. They continue to do so until the pod reaches its maturity and the larvae possibly feed from the sweet juice of the pods until the cotyledon is developed (Johnson and Siemens, 1997). Likewise, it has been mentioned that this bruchid introduces itself into the pods and into the first seed it may find, slithering through the pulp of the pod, until it finds a seed. (Johnson, 1983; Johnson and Siemens, 1997).

The second species in relative abundance was $M$. amicus, which oviposits only on green pods and their emergence perforations are used by other bruchid species to oviposit. Their reproduction is more probable in Parkinsonia and Acacia seeds, although it is also abundant in Prosopis seeds (Ramirez, 2013). Likewise the $M$. amicus female deposits eggs in June, only on immature pods, that have well developed cotyledons; it places the eggs randomly on the pod and occasionally, superposes eggs one on top of the other and the larvae penetrate the pod directly from the lower part of the egg (Johnson, 1983).

When comparing the insect abundance, with the results obtained by Aguado and Suarez (2006), in Santa Marta, Colombia, the difference that they obtained was a minimum of 65 individuals of Algarobius riochama
Kingsolver and a maximum of 1,156 in 100 pods of $P$. juliflora; while in this study the total amount of bruchids was higher (Table 1). This is probably due to environmental conditions, different fruiting stages, total of collected pods and types of collection of both studies.

Infestation index. Results of this study differed with what other authors have found, such as Silva et al. (2000) who found damages in the Chaco region in Argentina on Prosopis chilensis (Molina) Stuntz carob trees, depending on the month of the year, with values of $1.78,14,58$ and $85.6 \%$ for the months of February, March, April and May, respectively. Also, Solorio et al. (2004) assessed damages produced by A. prosopis, on mesquite pods, in two areas of the State of Durango, observing values of 48 and $32 \%$ damages, caused by only one species of bruchids. Furthermore, Aguado and Suarez (2006) assessed damages caused by $A$. riochama in $P$. juliflora pods in Colombia, in 14 different sites that ranged from 32.3 to $91.6 \%$, with a $55.9 \%$ damages average.

Percentage of harmed seed. A. prosopis larvae, present on mature pods, may introduce themselves into the first seed they find and cause harm, attacking the plant from the moment the immature pods begin to develop and continue even after the pods have matured and shall continue to feed until most of the pod has been destroyed (Johnson, 1983; Trujillo, 1993; Rodriguez et al., 2014). In Patagonia, Argentina, Cariaga et al. (2005), reported that Prosopis alpataco Phil seeds were infested $87 \%$ and $P$. denudans Benth $25 \%$, by the bruchid Rhipibruchus prosopis Kingsolver. Additionally, Palleres (2007), who assessed damage by insects on the seed of Prosopis flexuosa DC, found a total of 360 seeds of which $16 \%$ had lesions by Apion sp. and $4 \%$ was affected by Scutobruchus vinalicola Kingsolver and $80 \%$ had healthy seeds, with less damage. This situation could have been due to the amount of seeds and plant development as well as the environmental conditions of the zone, since said author carried out his research in Argentina. Likewise, Araiza et al. (2011) found that damages in Algarobius johnsoni Kingsolver seeds continue to increase until $44 \%$ is reached in the month of August.

Two parasitoid species were found: Urosigalphus sp. and Horismenus missouriensis of A. prosopis and $M$. amicus bruchids. The highest abundance for both species happened when the pods were immature (Table 2). Also, it is mentioned that Urosigalphus Ashmead is one of the 
most common genus of the Brachistini tribe (Braconidae: Helconinae) with approximately 100 species restricted to the western hemisphere. These are small endoparasitoid wasps, mainly of the Curculionid and Chrysomelidae (Bruchinae) (Arias-Penna, 2007), with a great variety of plant hosts (Aebi et al., 2008). There are references that some species of this genus prefer attacking bruchid eggs, on immature pods and during adult emergence, more than when the pod has matured; and therefore, they prosper when the bruchid females oviposit at the end of pod maturation (Traveset, 1991).

Horismenus sp. and Urosigalphus sp. species were also observed in mesquite weevils, in Bermejillo, Durango, where Urosigalphus sp. was more abundant (Ramirez, 2011). Likewise, H. missouriensis has been observed as a parasitoid of the Bruchidae family (Hansson et al., 2004) and of Lepidoptera (Bautista-Martinez et al., 1998) and it has been found as a parasite of different Acanthoscelides species, in beans, in Morelos and Michoacan (Bonet, 2008). Johnson (1983) mentions that Urosigalphus bruchi Crawford (Hymenoptera: Braconidae) destroys 4 to $7 \%$ of Prosopis spp. bruchid larvae and Urosigalphus sp. has been observed parasitizing nanche (Malpighia mexicana), in Oaxaca (Jarquin, 2007). H. missouriensis, has been found in Ipomoea parasitica (Kunth) G. Donn seeds as parasitoids of Megacerus tricolor (Suffrian) and Megacerus callirhips (Sharp) bruchids; the same parasitoid was found in seeds of Acacia coulteri A. Grey, on Merobruchus santarosae Kingsolver and Stator limbatus (Horn) and in seeds of Lysiloma acapulcense (Kunth) Benth as parasitoid of Acanthoscelides mimosicola Johnson and Sennius morosus (Sharp) (Romero, 2008).

It must be mentioned that 15 Lepidoptera larvae were collected from the pod, nevertheless, only one exemplar reached the adult stage and the species could not be determined, even though harm on various species of Prosopis by various species of Lepidoptera have been reported (Ward et al., 1977).

In relation with Formicidae that emerged from the pods, it could be said that these individuals entered through pod holes when the pods were immature and remained there feeding from the endocarp until the pod matured and then they emerged. Crematogaster depilis has been reported for Prosopis sp. Acacia sp., Larrea and Ocotillo; and three Forelius species for P. glandulosa, P. laevigata and P. nigra (Ward et al., 1977).

\section{Conclusion}

Bruchids cause important damage to $P$. laevigata causing losses of pods and seeds in different development stages (immature and mature pods). Furthermore, there is a reduction of fruit quality and therefore they are not ideal for animal consumption.
When Algarobius prosopis, Mimosestes amicus is present, feeding itself from the internal part of the mesquite pod and seeds, there is difficulty in the detection and assessment of harm, as well as in their control. Nevertheless, when parasitoids are present, it is recommended that biology and ecology studies be carried out, on these natural enemies, in order to establish an integral handling plan for these bruchids.

A good recommendation is the removal of pods that are on the floor and on trees, after the mesquites enter into their dormancy stage, in order to avoid oviposition by bruchids on those pods, establishing thus a reservoir of these insects, in the mesquite areas. The plants should be supervised annuals, in order to monitor bruchid presence and continue establishing its behavior and infestation proportion, in pods and seeds, contributing thus to the biological knowledge of bruchids, including their adaptability to the environmental conditions during each year and season, in the study area.

\section{Acknowledgment}

This study is part of a project for master's degree of K.L. Reséndez and was carried out under the framework of the projects, code: 20131840 and 20141072 of the Secretaría de Investigación y Posgrado of the Instituto Politecnico Nacional (IPN). Aid was received from the Consejo Nacional de Ciencia y Tecnología and the Estimulo Institucional de Formacion de Investigadores del IPN. Special thanks are given to Dr. Gabriela Meneses amd M.C. Rebeca Peña Martínez for the review of the manuscript and their suggestions; to M.C. Alejandro Leal Saenz and Biologist Gerardo Hinojosa Ontiveros for support during the field work for this research; to Mr. Lorenzo Pereyra and community land owners of Aquiles Serdan, for their permission to carry out this field study in their mesquite fields.

\section{Author's Contributions}

The authors of this research paper participated directly in the planning, execution and preparation of the manuscript.

\section{Ethics}

This paper is original and contains unpublished material. Authors have read and approved the manuscript and there is no conflict of interest for any of them.

\section{References}

Aebi, A., T. Shani, C. Hansson, J. Contreras-Garduno, and G. Mansion et al., 2008. The potential of native parasitoids for the control of Mexican bean beetles: A genetic and ecological approach. Biol. Control, 47: 289-297.

DOI: 10.1016/j.biocontrol.2008.07.019 
Aguado, A. and H. Suárez, 2006. Impacto del ataque de Algarobius riochama Kingsolver (Coloptera: Bruchidae) sobre Prosopis juliflora (SW) DC en la zona urbana de Santa Marta. Revista Intropica, 3: $13-20$.

Alvarez, J.A. and P.E. Villagra, 2009. Prosopis flexuosa D.C. (Fabaceae, Mimosoideae). Kurtziana, 35: 46-63.

Amdor, B.A., J.E. Sloseer, G.B. Idol, M.N. Parajulee and W.E. Pinchak et al., 2006. Pupulations dynamics and response to mesquite pod supplementation for Algarobius bottimeri and Minosestes amicus. Southwestern Entomol., 31: 103-112.

Arellano, D.S., 1996. Determinación del Potencial Productivo del Mezquite (Prosopis spp) en el Municipio de San Juan de Guadalupe, Durango. 1st Edn., Universidad Autonoma Chapingo, Unidad Regional Universitaria de Zonas Aridas, Bermejillo, Durango, pp: 63.

Arias-Penna, D.C., 2007. New geographical records of the genus Urosigalphus Ashmead, 1889 (Hymenoptera: Braconidae, Helconinae) for Colombia. Boletín del Museo de Entomología de la Universidad del Valle, 8: 1-9.

Aubeterre, D.R., J. Principal, C. Barrios and Z. Graterol, 2012. Insectos plaga en vainas de Acacia tortuosa y Prosopis juliflora para consumo animal en las zonas semiáridas del estado Lara, Venezuela. Zootecnia Trop., 30: 147-153.

Bautista-Martinez, N., J.L. Carrillo-Sanchez, H. Bravo-Mojica and S.D. Koch, 1998. Natural parasitism of Phyllocnistis citrella (Lepidoptyera: Gracillariidae) at Cuitlahuac, Veracruz, Mexico. Fla. Entomol., 81: 30-37. DOI: 10.2307/3495994

Bonet, A., 2008. New hosts, host plants and distribution records for Horismenus (Hymenoptera: Eulophidae) species in a Bruchid beetle parasitoid guild attacking type Phaseolus coccineus and P. vulgaris in central Mexico. Florida Entomol., 91: 698-701.

Burkart, A., 1976. A monograph of the genus Prosopis (Leguminosae subfam. Mimosoideae). J. Arnold Arboretum, 57: 219-249.

Cariaga, E.R., R.P. Agüero, A.D. Ravetta and E.A. Vilela, 2005. Differences in production and mortality of reproductive structures in two Prosopis L. (Mimosaceae) shrub species from Patagonia, Argentina. J. Arid Environ., 63: 696-705. DOI: $10.1016 /$ j.jaridenv.2005.03.025

Carrillo, F.R., 2006. Efecto de la poda sobre el potencial productivo de mezquites nativos (Prosopis glandulosa Torr. var. glandulosa) en la Comarca Lagunera. MSc Thesis, Unidad Regional Universitaria de Zonas Áridas, Universidad Autónoma Chapingo. Bermejillo, Durango, México.

Diaz, C.A., 1995. Guia Para los Cultivos y Aprovechamiento de Los Algarrobos o Trupillos. 1st Edn., Santa Fe de Bogota-Convenio Andres Bello, Colombia, Series Ciencia y Ttecnología, pp: 41.
Flores-Flores, J.D., O.M. Garcia, J.A. Anaya, J.A. Perez and A. Cruz-G et al., 2006. Estado de Salud de Las Poblaciones de Mezquite Prosopis glandulosa y $P$. Laevigata, en el Desierto de Coahuila. In: Libro Cientifico Anual, Agricultura, Ganaderia u Ciencia Forestal en la UAAAN. In: Estrada and Vullarreal (Eds.), Avances y Resultados de Proyectos de Investigación, pp: 201-207.

Garcia-Andrade, M., R.F. Gonzalez-Laredo, N.E. Rocha-Guzmán, J.A. Gallegos-Infante and M. Rosales-Castro, 2013. Mesquite leaves (Prosopis laevigata), a natural resource with antioxidant capacity and cardioprotection potential. Ind. Crops Products, 44: 336-432.

DOI: 10.1016/j.indcrop.2012.11.030

Hansson, C., A. Aebi and B. Benrey, 2004. Horismenus species (Hymenoptera: Eulophidae) in a bruchid beetle parasitoid guild, including the description of a new species. Zootaxa, 548: 1-16.

INIFAP, 2013. Datos del clima, estación Valle Florido, municipio de Durango. Instituto Nacional de Investigaciones Forestales, Agricolas y Pecuarias.

Jarquin, L.R., 2007. Parasitoides asociados a insectos en frutos de nanche (Malpighia mexicana) en Oaxaca. MSc. Thesis, Centro Interdisciplinario de Investigación para el Desarrollo Integral Regional Unidad Oaxaca, Instituto Politécnico Nacional, México.

Johnson, C.D., 1983. Manual Sobre Insectos que Infestan la Semilla de Prosopis. 1st Edn., Northern Arizona University. Flagstaff, Organización de las Naciones Unidas para la Agricultura y la Alimentación Roma, pp: 59.

Johnson, C.D. and D.H. Siemens, 1997. Distribution, oviposition guilds, behavior and new host records from Latin American for Algarobius Bridwell, Scutobruchus Kingsolver and Pseudopachymerina spinipes (Erichson) (Coleoptera: Bruchidae). Coleopterists Bull., 51: 37-42.

Kingsolver, M.J., 2004. Handbook of the Bruchidae of the United States and Canada (Insecta, Coleoptera). United States Department of Agriculture.

Loeza, C.J.M., 2007. Modificación enzimatica de la goma de mezquite para la obtención de L-arabinosa. PhD. Thesis, Universidad Autónoma Metropolitana, México.

Meza, S.R. and E.L. Osuna, 2003. Estudio dasometrico del mezquite en la zona de las Pocitas, B.C.S. Folleto cientifico No.3. Instituto Nacional de Investigaciones Forestales, Agricolas y Pecuarias. Campo experimental Todos Santos. Baja California Sur, México.

Moran, V.C., J.H. Hoffmann and H.G. Zimmermann, 1993. Objectives, Coinstraints and tactics in the biological control of mesquite weeds (Prosopis) in South Africa. Biol. Control, 3: 80-83.

DOI: $10.1006 /$ bcon. 1993.1013 
Moron, M.A. and R.A. Terron, 1988. Entomologia Practica. 1st Edn., Instituto de Ecologia, A.C. México, pp: 503.

Palacios, R.A., S.P. Hoc, D.A. Burghardt and E.A. Vilela, 2000. Biodiversidad y Clasificacion, Estrategias Adaptativas, Reproductivas e Importancia Economica. In: El Mezquite Árbol de Usos Múltiples, Frias-Hernandez, J.T., V. Olalde-Portugal and E.J. Verron-Carter, (Eds.), Estado actual del conocimiento en México, Universidad de Guanajuato, México, pp: 13-35.

Palacios, R.A., 2006. Los mezquites Mexicanos: Biodiversidad y Distribución Geográfica. Bol. Soc. Argent. Bot., 41: 99-121.

Palleres, E., 2007. Efecto de la depredacion de insectos sobre semillas de Prosopis flexuosa (Fabaceae, Mimosoideae) y su relación con el consumo por roedores pequeños del desierto del monte. Universidad del Aconcagua, Mendoza, Argentina.

Ramirez, G.M., 2011. Exploracion de parasitoides de bruchidos (Coleoptera: Bruchidae) del mezquite en Bermejillo, Dgo. Reunión Nacional de Investigación de Recursos Bioticos de Zonas Aridas. Universidad Autonoma Chapingo-Unidad Regional de Zonas Aridas, Bermejllo, Dgo, México, pp: 47-50.

Ramirez, S.A., 2013. Estudio faunistico de bruquidos (Coleoptera: Bruchidae) en el estado de Mexico. PhD Thesis, Colegio de Postgraduados, Campus Montecillo, Texcoco, Estado de Mexico.

Reyes, L., L.J. Aviña, A. Pinedo and E. Unzueta, 2012. Descripción del barrenador del mezquite (Prosopis spp.) (Coleoptera, Cerambycidae, Cerambicinae), en el poblado Lauro del Villar, del municipio de Nombre de Dios, Durango. Entomología Mexicana. Montecillos, Estado de México, 11: 822-828.

Romero, G.G., 2008. Gorgojos de la familia Bruchidae (Insecta: Coleoptera) asociados a semillas de plantas silvestres destinadas para germoplasma. MSc Thesis, Colegio de Postgraduados, Campus Montecillo, Texcoco, Estado de México.

Rodriguez, S.E.N., G.E.R. Martínez, B.R. Valverde, R.M. Ruiz and M.D.L.C.C. Hermida, 2014. Análisis técnico del árbol del mezquite (Prosopis laevigata Humb. \& Bonpl. Ex Willd.) en México. Ra Ximhai., 10: 173-193.

Ruiz, T.D.R., 2011. Uso potencial de la vaina de mezquite para la alimentación de animales domésticos del Altiplano Potosino. MSc Thesis, Facultad de Ciencias Químicas, Universidad Autonoma de San Luis Potosi.

Araiza, M.D.S., J.R. Nápoles and E.G. Aguilera, 2011. Contribución al estudio de los brúquidos (insecta: Coleóptera) asociados a fabaceas arbustivas. Acta Universitaria, 11: 26-32. DOI: 10.15174/au.2001.324
Salas-Araiza, M.D., J. Romero-Napoles and E. Aguilera-García, 2001. Contribución al estudio de los brúquidos (insecta: Coleóptera) asociados a fabaceas arbustivas. Acta Universitaria, 11: 26-32. DOI: 10.15174/au.2001.324

Silva, M.P., M.J. Martínez, R. Coirini, M.A. Brunetti and M. Balzarini et al., 2000. Valoracion nutritiva del fruto del Algarrobo Blanco (Prosopis chilensis) bajo distintos tipos de almacenamiento. Multiquenia, 9: $65-74$.

Solorio, R.I., F.L. Gomez, R.E.G. Ramos, C.E. Santamaria and M.J.A. Salazar, 2004. Evaluacion de daños por el gorgojo Algarobius prosopis Le Conte en la vaina de mezquites Prosopis spp de la Comarca Lagunera. Revista Chapingo Serie Zonas Aridas, 3: 111-114.

Traveset, A., 1991. Pre-dispersal seed predation in Central American Acacia farnesiana: Factors affecting the abundance of co-occurring bruchid beetles. Oecologia, 87: 570-576. DOI: $10.1007 / \mathrm{BF} 00320422$

Trucios-Caciano, C.R., L.M. Valenzuela-Nuñez, J.C. Rios-Saucedo, M. Rivera-Gonzalez and J. Estrada-Avalos, 2012. Cambio de uso del suelo en Coahuila y Durango. Revista Chapingo Serie Zonas Aridas, 6: 68-74.

Trujillo, M.J.R., 1993. La superación de la pobreza en el medio rural de las zonas aridas y semiaridas. La contribución del mezquite. Instituto Politécnico Nacional, Escuela Superior de Economia, Mexico.

Vallejo, V.J.A., R.J. Ocampo, R.C. Martínez, R.T. Caciano and M.R. Gonzalez, 2012. Potencial productivo y cambio de uso de suelo en poblaciones de mezquite (Prosopis spp.) del norte-centro de Mexico. Agrofaz, 12: 89-98.

Díaz, J.V., R.J. Ibarra, E.H.C. Oviedo and C.P. Talavera, 2004. El mezquite en la comarca lagunera: Su dinámica, volumen maderable y tasas de crecimiento anual. Agrofaz, 4: 633-648.

Ward, R.C., W.O. Brien, L.B.O. Brien, D.E. Foster and E.W. Huddleston, 1977. Annotated Checklist of New World Insects Associated with Prosopis (Mesquite). 1st Edn., Department of Agriculture, Agricultural Research Service, pp: 115.

Zachariades, C., H.J. Hoffmann and P.A. Roberts, 2011. Biological control of mesquite (Prosopis species) (Fabaceae) in South Africa. African Entomol., 19: 402-415. DOI: 10.4001/003.019.0230 